\title{
A STUDY, BY SIMULTANEOUS CLEARANCE TECHNIQUES, OF SALICYLATE EXCRETION IN MAN. EFFECT OF ALKA- LINIZATION OF THE URINE BY BICARBONATE ADMINISTRATION; EFFECT OF PROBENECID ${ }^{1}$
}

\author{
By ALEXANDER B. GUTMAN, T. F. YU, AND JONAS H. SIROTA 2 \\ (From the Department of Medicine, The Mount Sinai Hospital, and the Department of Medi- \\ cine, Columbia University College of Physicians and Surgeons, New York, N. Y.)
}

(Submitted for publication December 6, 1954; accepted January 26, 1955)

In the course of a study of the uricosuric effect of salicylate in gouty subjects, and its potentiation by bicarbonate administration (1), it became evident that interpretation of the findings would require further investigation into the processes regulating salicylate excretion in man. These are exceedingly complex, as indicated in recent reviews of the subject by Gross and Greenberg (2) and P. K. Smith (3).

According to Kapp and Coburn (4), about 80 per cent of administered salicylate is recoverable as the salicyl radicle in the urine of normal man. The remainder is converted in part to gentisic acid and a gentisic-salicyluric acid compound. Some 20 per cent of the salicyl radicle recovered in the urine in man appears as free salicylate, at least when salicylate is given orally; the remainder is excreted in conjugated form, combined either with glycine to form salicyluric acid ( 55 to 60 per cent) or with glucuronic acid (20 to 25 per cent). Salicyl conjugates are not detectable in the blood (5).

Upon administration of sodium bicarbonate, the rate of urinary excretion of salicylate is greatly enhanced (6-8). With increasing alkalinity of the urine, the proportion of free salicylate rises from approximately 20 per cent (after oral administration) to 60 to 70 per cent or more of the total urinary salicylate $(6-8)$.

The prevailing view (9) is that, in man, free salicylate is filtered at the glomerulus and in part reabsorbed in the tubules. A variable proportion of the free salicylate, under ordinary circumstances

\footnotetext{
1 This work was supported by grants-in-aid from the National Institute of Arthritis and Metabolic Diseases, National Institutes of Health; The Arthritis and Rheumatism Foundation, New York Chapter; and the American Heart Association.

2 Present address: San Jose, Calif.
}

the major proportion, is conjugated in the tubules and is then presumably excreted, as salicyl conjugate, by the tubules. Alkalinization of the urine by concomitant administration of sodium bicarbonate is believed to enhance salicylate clearance by diminishing reabsorption of salicylate by the tubules.

There appears to be no record in the literature of simultaneous renal clearance studies of salicylate, inulin, and p-aminohippurate in man. The present report summarizes results obtained by these techniques, including observations on the effect of alkalinization of the urine by concomitant intravenous infusion of sodium bicarbonate. The effect of probenecid (Benemid ${ }^{\circledR}$ ) on salicylate clearance was also studied.

\section{METHODS}

The experiments were conducted in gouty subjects since our initial interest was in concomitant changes in urate clearance (1). The 14 patients (ages 28 to 54) selected for study were in the non-tophaceous stage of the disorder and gave no clinical or laboratory indication of overt cardiovascular or renal disease. All had been maintained on a constant diet low in purine and restricted in protein (60 to $75 \mathrm{gm}$. per day) preceding study and were in the morning post-absorptive state at the time of the experiment. Urine flow not less than $3 \mathrm{ml}$. per min. (usually 6 to $10 \mathrm{ml}$. per min.) was maintained throughout the period of study by liberal ingestion of water.

Glomerular filtration rate and renal plasma flow were estimated as previously described (10), using standard methods (11). Priming and sustaining infusions of inulin and p-aminohippurate in isotonic saline solution were administered intravenously by means of a Bowman infusion pump at rates calculated to maintain plasma concentrations of $30 \mathrm{mg}$. per cent and $2 \mathrm{mg}$. per cent, respectively. Thirty minutes were allowed for equilibration. Three control inulin clearance periods, each of 15 to 20 minutes' duration, were first obtained in each subject. After the third control clearance period, sodium salicylate was administered intravenously to 10 subjects. 
Patients A. S., J. H., D. R., and A. M. received $4.5 \mathrm{gm}$. in $500 \mathrm{ml}$. saline solution at a rate of $4 \mathrm{ml}$. per min. until the end of the experiment. As this slow rate of infusion did not always yield satisfactorily sustained plasma salicylate levels, the remaining subjects first received a priming dose of $3.0 \mathrm{gm}$. sodium salicylate in $100 \mathrm{ml}$. saline solution at a rate of 8 to $10 \mathrm{ml}$. per min., then a sustaining infusion of $2.0 \mathrm{gm}$. in $500 \mathrm{ml}$. saline solution at a rate of $4 \mathrm{ml}$. per min. After allowing 20 to 30 minutes for equilibration, three 20 -minute clearance periods were obtained. Then intravenous administration of 7.5 per cent sodium bicarbonate was begun and, after allowing 20 to 30 minutes for equilibration, urine and blood samples were collected for three or more additional 20minute periods. Patients A. S., J. H., D. R., and A. M. first received $3.75 \mathrm{gm}$. sodium bicarbonate within 3 to 5 minutes, followed by infusion of $11.25 \mathrm{gm}$. more slowly over a span of approximately one hour, in combination with the sustaining solution of sodium salicylate. Patients H. G., S. L., L. C., J. S., B. R., and H. W. were first given $11.25 \mathrm{gm}$. sodium bicarbonate by rapid injection (12 to 15 minutes), then $3.75 \mathrm{gm}$. (in Case H. W., $7.5 \mathrm{gm}$.) sodium bicarbonate more slowly over a period of one hour, in each instance together with the sustaining solution of sodium salicylate.

Urine samples were secured by means of an in-dwelling catheter and at the end of each clearance period the bladder was emptied completely after washing with 20 $\mathrm{ml}$. saline solution. Blood samples were drawn at the mid-points of the first and third collection periods during the control, salicylate, and salicylate and bicarbonate infusions. Representative plasma concentrations of inulin, p-aminohippurate and total salicylate for each clearance period were obtained by plotting the concentrations in the samples semi-logarithmically against time and extrapolating back 2.5 minutes (approximate urine delay time) from the mid-time of each urine collection period.

In four additional subjects the clearance studies were performed in the same way except that, instead of bicarbonate, probenecid $(20 \mathrm{mg}$. of the sodium salt per $\mathrm{kg}$. body weight) was infused at the end of the third salicylate clearance period.

Inulin in plasma and urine was determined by the method of Schreiner (12), p-aminohippurate by the method of Smith, Finkelstein, Aliminosa, Crawford, and Graber (13). The pH of the urine was measured at the bedside, immediately after delivery, by a Cambridge glass electrode $\mathrm{pH}$ meter. Salicylate was determined by the method of Brodie, Udenfriend, and Coburn (5) in plasma, plasma ultrafiltrate, urine before hydrolysis ("free" urinary salicylate) and after acid hydrolysis ("total" urinary salicylate). Hydrolysis was performed as described by Williams and Leonards (7), autoclaving 1 to $2 \mathrm{ml}$. diluted urine with $0.5 \mathrm{ml}$. $6 \mathrm{~N} \mathrm{HCl}$ for three hours at a pressure of 20 lbs. per sq. inch. In the case of "free" salicylate, the values are too high because of the presence and chromogenicity of salicyluric acid, which gives 35 per cent as much color with the ferric nitrate reagent as salicylic acid; the glucuronide is not chromogenic $(5)$. No correction $(6,8)$ was attempted, how- ever, because under the conditions of the acute experiments most of the salicyl radicle (except in Case A. M.) was excreted in the form of unconjugated salicylate even before sodium bicarbonate was administered.

Ultrafiltration of the plasma salicylate was carried out by means of a Simms-Sanders "surge" apparatus (14). The concentration of ultrafiltrable salicylate in plasma was expressed in terms of plasma water by use of the formula of McLean and Hastings (15), a serum protein concentration of $6 \mathrm{gm}$. per cent being assumed.

In calculating "free" salicylate clearances, urinary excretion of "free" salicylate (UV) was represented by mg. "free" salicylate excreted per minute, as determined in unhydrolyzed urine; plasma concentration (P) was expressed as mg. salicylate per ml. plasma ultrafiltrate. For "total"salicylate "clearances," UV values were represented by mg. "total" salicylate excreted per minute, as determined in hydrolyzed urine. $\mathrm{P}$ values were again represented by $\mathrm{mg}$. salicylate per $\mathrm{ml}$. plasma ultrafiltrate since the plasma concentrations of salicyl conjugates are too low for precise measurement by available techniques. Excretion of gentisic acid and related degradation products was not considered in calculating salicylate clearance because there is no evidence that these substances are formed in the kidney.

\section{RESULTS}

\section{Total and ultrafiltrable plasma salicylate levels (Table I)}

Sodium salicylate was infused at a rate sufficient to maintain plasma salicylate levels above $15 \mathrm{mg}$. per cent in most experiments. The marked fall in plasma salicylate concentration which ordinarily occurs when the salicylate clearance is increased by administration of an alkalinizing agent (16) is masked under the conditions of these experiments by the continued infusion of sodium salicylate. The changes in plasma total salicylate $\left(P_{B}\right)$ recorded in Table $I$ therefore simply reflect the rate of salicylate injection.

Most of the salicylate present in plasma is known to be bound to plasma proteins $(6,7,17-20)$, hence is not filtered at the glomerulus. The results of 50 plasma ultrafiltrations carried out in the course of this study are summarized in Figure 1. The linear distribution of points indicates that the ratio of ultrafiltrable plasma salicylate to total plasma salicylate is relatively constant, $30 \pm 10$ per cent (mean 34 per cent) in terms of plasma water, over the range 2.0 to $35 \mathrm{mg}$. per cent total plasma salicylate. At levels above this the curve swings sharply upward, as described by previous investigators $(6,7,19)$, and as suggested by the one 


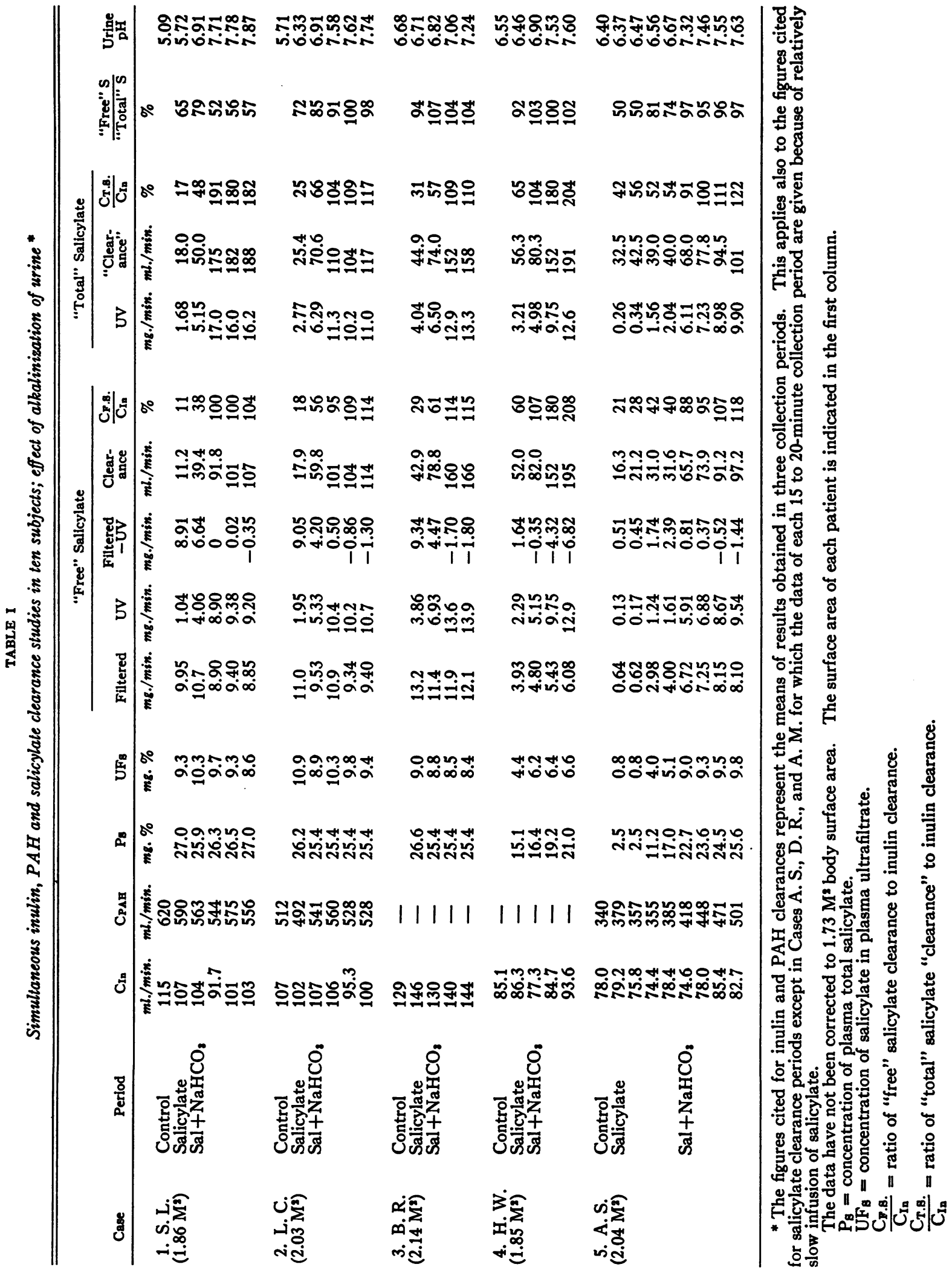




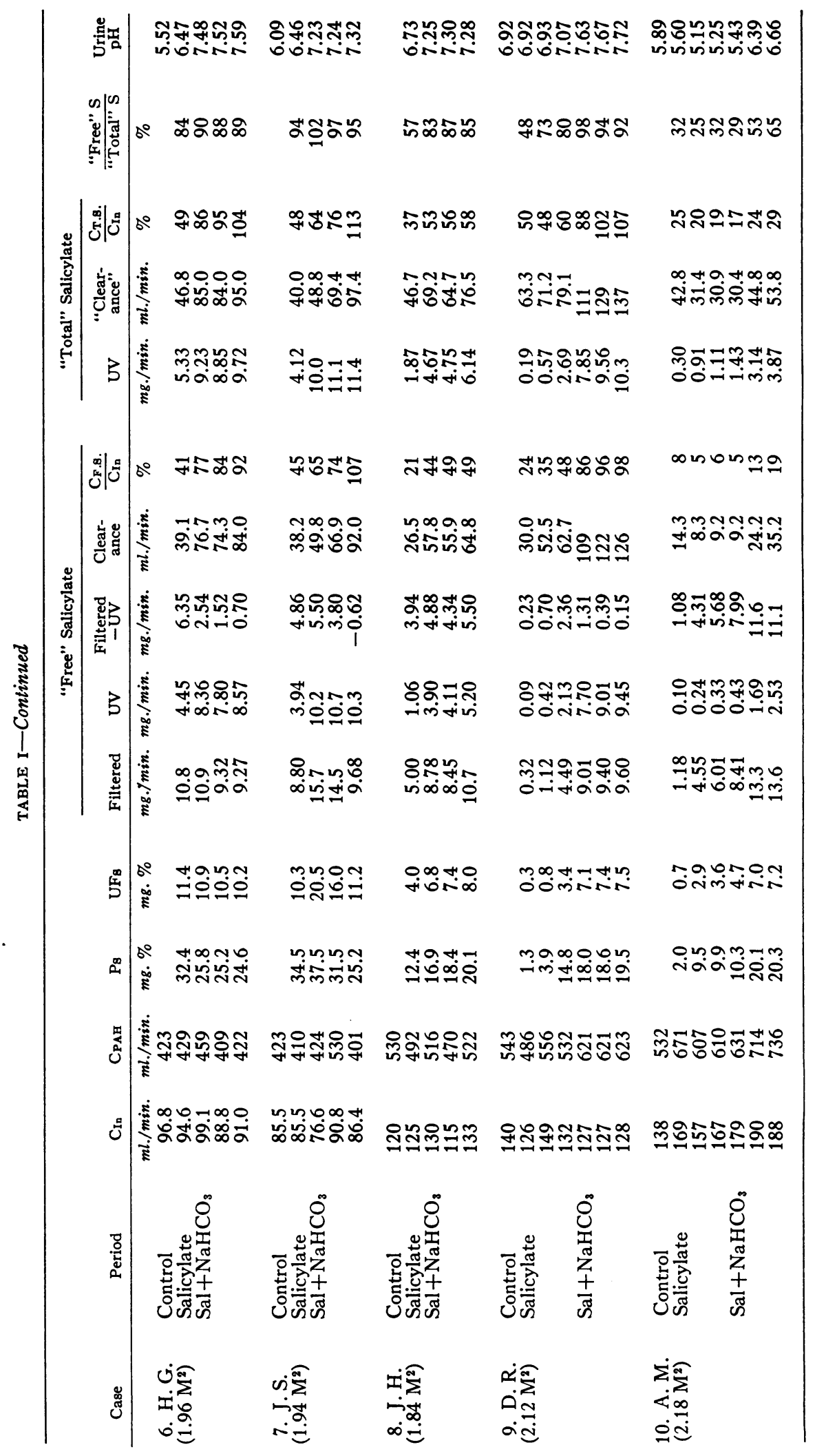




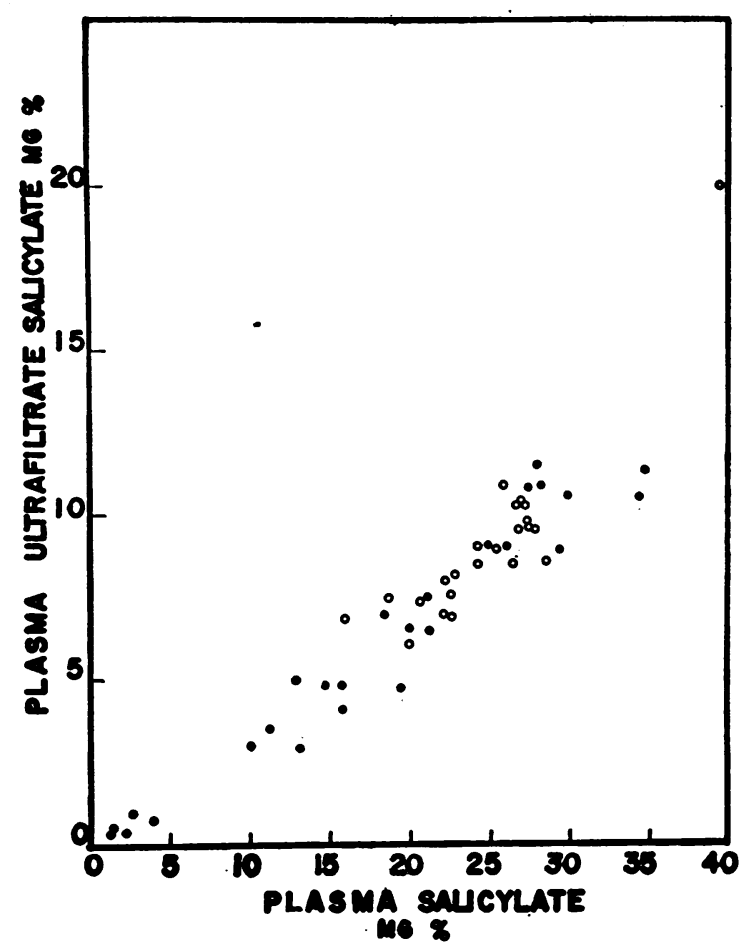

Fig. 1. Relation of Plasma Ultrafiltrate Salicylate to Plasma total Salicylate

All concentrations are expressed in terms of plasma water. Solid dots represent values obtained when sodium salicylate alone was infused, hollow dots when sodium salicylate and sodium bicarbonate were infused concurrently.

point in this range in Figure 1. At such high plasma salicylate levels the capacity of the plasma proteins to bind salicylate apparently is exceeded and the excess circulates as free salicylate.

Administration of sodium bicarbonate does not affect the ultrafiltrability of the plasma salicylate (7), as shown in Figure 1.

Effect of salicylate on glomerular filtration rate and renal plasma flow (Table I)

$\mathrm{C}_{\text {In }}$ in the control period was within the normal limits of variation except for somewhat lowered values in Cases H. W., A. S., H. G., and J. S. (Table I). The mean $\mathrm{C}_{\text {In }}$ of the control periods was $109 \mathrm{ml}$. per min. Infusion of sodium salicylate alone or combined with sodium bicarbonate did not cause any consistent change, the mean $\mathrm{C}_{\text {In }}$ of these periods being 112 and $116 \mathrm{ml}$. per min., respectively. $\mathrm{C}_{\mathrm{PAB}}$ also showed no consistent change in the salicylate and salicylate $+\mathrm{NaHCO}_{3}$ periods, the means being $490 \mathrm{ml}$. per min. in the control period and 493 and $535 \mathrm{ml}$. per min., respectively, in the two experimental periods.

\section{Salicylate clearance; effect of sodium bicarbonate infusion (Table I)}

The "free" salicylate clearance ranged from 8.3 to $62.7 \mathrm{ml}$. per min. (mean $29.7 \mathrm{ml}$. per min.), the "total" salicylate "clearance" from 18 to $79 \mathrm{ml}$. per min. (mean $44.2 \mathrm{ml}$. per min.). Low salicylate clearance values occurred in association with the more acid urinary $\mathrm{pH}$ levels.

Upon infusion of sodium bicarbonate, the "free" and "total" salicylate clearance invariably rose. In those clearance periods in which the urine $\mathrm{pH}$ exceeded 7.0, the range in "free" salicylate clearance was 49.8 to $195 \mathrm{ml}$. per min. (mean $100 \mathrm{ml}$. per min.), that of "total" salicylate "clearance"

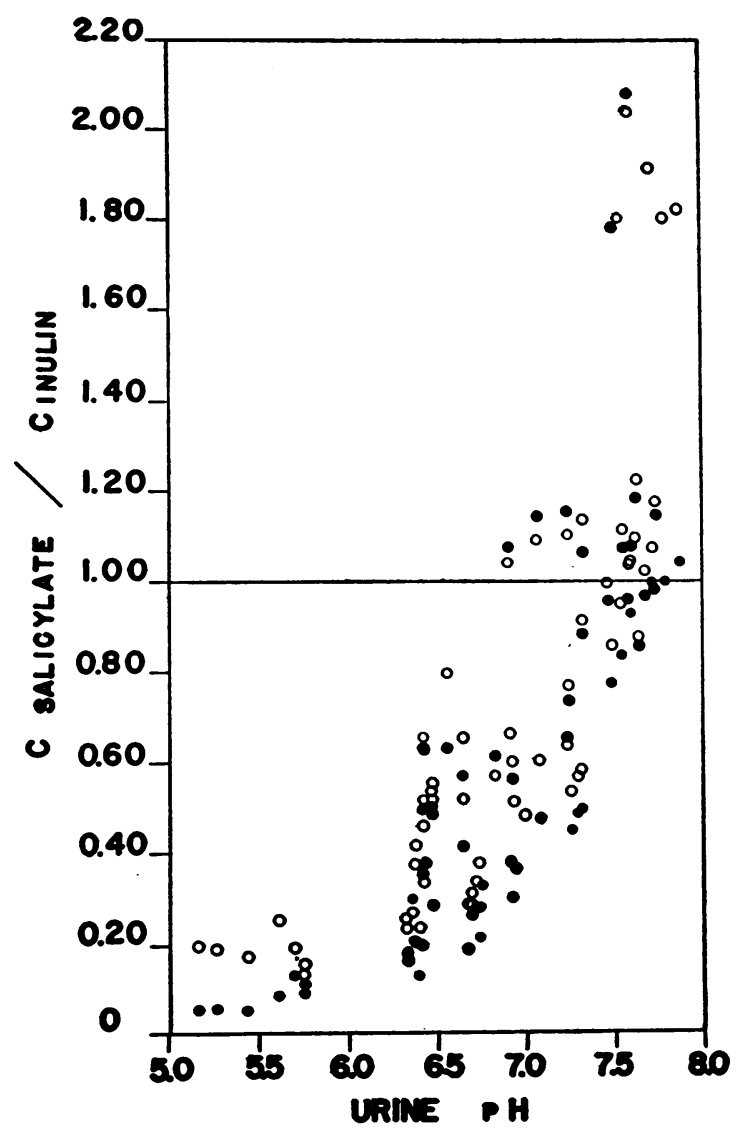

Fig. 2. Relation of Salicylate/Inulin Clearance Ratios to URINe PH bEFORE AND AFTER Alkalinization of the URINe by Sodium Bicarbonate Infusion

Solid dots represent "free" salicylate, hollow dots "total" salicylate. 
was 49 to $191 \mathrm{ml}$. per min. (mean $113 \mathrm{ml}$. per min.). Alkalinization of the urine by infusion of sodium bicarbonate effected an approximately three-fold mean rise in salicylate clearance.

The mean ratio of "free" to "total" salicylate excreted in the urine rose from 0.71 to 0.91 when the urine was alkalinized by infusion of sodium bicarbonate. The initial ratio, 0.71 , was considerably higher than the ratio of approximately 0.25 observed after oral administration of salicylate. This high initial ratio is ascribed to the sustained intravenous infusion of sodium salicylate at a rate rapid enough to maintain high plasma salicylate levels and UV values, and presumably in excess of the rate and capacity of tubular conjugation; and the fact that the initial urine $\mathrm{pH}$ exceeded 6.0 in most instances (Table I).

The clearance ratios, $\mathrm{C}_{\text {"free" }} \mathrm{s} / \mathrm{C}_{\mathrm{In}}$ and $\mathrm{C}$ "total" $\mathrm{s} /$ $\mathrm{C}_{\text {In }}$, show the same general trends as the salicylate clearance, since $\mathrm{C}_{\text {In }}$ did not change consistently. Figure 2 brings out more clearly the effect of alkalinization of the urine upon "free" and "total" salicylate clearance in relation to the inulin clearance. The "free" salicylate/inulin clearance ratio exceeded 1.0 in 11 of 15 observations at urinary $\mathrm{pH}$ levels above 7.5 ; in 3 of 12 observations at urinary $\mathrm{pH}$ levels of 7.0 to 7.5 ; and only once in
34 observations at urinary $\mathrm{pH}$ levels below 7.0. A clearance ratio equal to or greater than 1.0 was obtained in at least one salicylate + bicarbonate collection period in six of eight patients whose urinary $\mathrm{pH}$ was brought to levels exceeding 7.3.

\section{Effect of sodium bicarbonate infusion on "net" tubular reabsorption of "free" salicylate}

Table I includes a recalculation of the clearance data to indicate the "net" tubular reabsorption of "free" salicylate (filtered load minus UV) at different levels of plasma salicylate, and the effect of alkalinization of the urine upon this quantity. These relationships are brought out more clearly in Figure 3 in which the data in individual cases are plotted as lines connecting points representing "net" tubular reabsorption of "free" salicylate before and after infusion of sodium bicarbonate. In the few cases with initial urine $\mathrm{pH}$ below 6.0, more than 90 per cent of the filtered "free" salicylate is reabsorbed. As the urine $\mathrm{pH}$ rises the "net" tubular reabsorption declines, very sharply as the range of alkalinity is approached and reached. At urine $\mathrm{pH}$ levels in excess of 7.5, negative values are obtained, reflecting accumulation utilizing the energy of a $\mathrm{pH}$ gradient and/or tubular excretion of "free" salicylate.

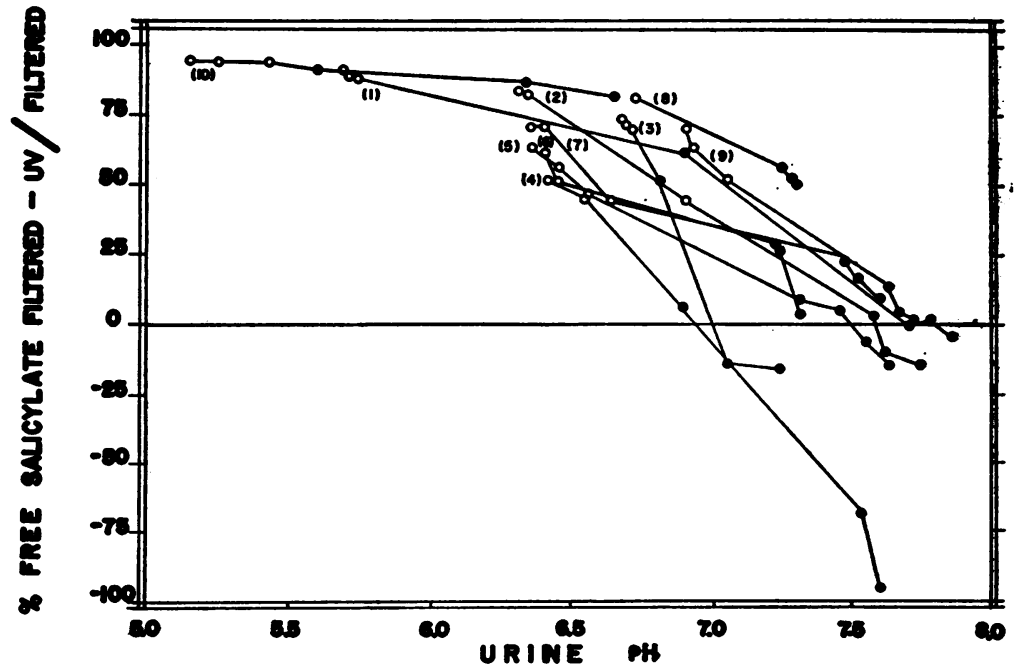

Fig. 3. Relation of "Net" Reabsorption of "Free" Salicylate at Varying Salicylate Loads to Urine PH

Each line connects points relating to a single patient, identified by a number corresponding to the case number in Table $I$. Hollow dots represent values obtained when sodium salicylate alone was infused, solid dots when sodium salicylate and sodium bicarbonate were infused concurrently. 
Effect of probenecid on salicylate clearance

Infusion of probenecid depressed urinary excretion of "total" and "free" salicylate in each of the four patients studied (Table II). The mean fall in salicylate/inulin clearance ratios was 33 per cent for "total" salicylate and 40 per cent in the case of "free" salicylate. These declines occurred despite a slight increase in $\mathrm{pH}$ of the urine. In accord with previous findings (10), $\mathbf{C}_{\mathbf{P A B}}$ was depressed, from 498 to $380 \mathrm{ml}$. per min. and from 495 to $355 \mathrm{ml}$. per min. in the two cases studied (Table II). $\mathrm{C}_{\text {In }}$ is not significantly affected by probenecid (10).

\section{DISCUSSION}

In the present study, standard simultaneous clearance techniques for the measurement of discrete renal functions were applied to the renal excretion of salicylate in an attempt to assess the relative importance of each phase of a complex four-phase system involving filtration at the glomerulus, tubular reabsorption, tubular conjugation, and tubular excretion. There are additional excretory processes implicating extra-renal oxidation of salicylate to gentisic acid and related compounds, and renal excretion of these metabolic products, but they will not be considered in this discussion.

Before proceeding to an analysis of each phase of the renal excretion of salicylate and salicyl conjugates, certain limitations in procedure and interpretation should be pointed out. In the case of "total" salicylate, currently available analytical methods do not permit precise measurement of individual salicyl conjugates in the urine or their detection in plasma. The values cited for UV and $\mathrm{P}$ consequently do not fulfill the requirements for calculation of valid clearance data and will not be so considered. In the case of "free" salicylate, the values for $P$ probably include undetectably small quantities of salicyl conjugates and the UV values do not take into account the (weak) chromogenicity of salicyluric acid. The error involved is small, however, in view of the high ratios of "free" to "total" salicylate obtained, particularly upon alkalinization of the urine. The data for filtration and excretion of "free" salicylate would therefore appear to be generally applica-

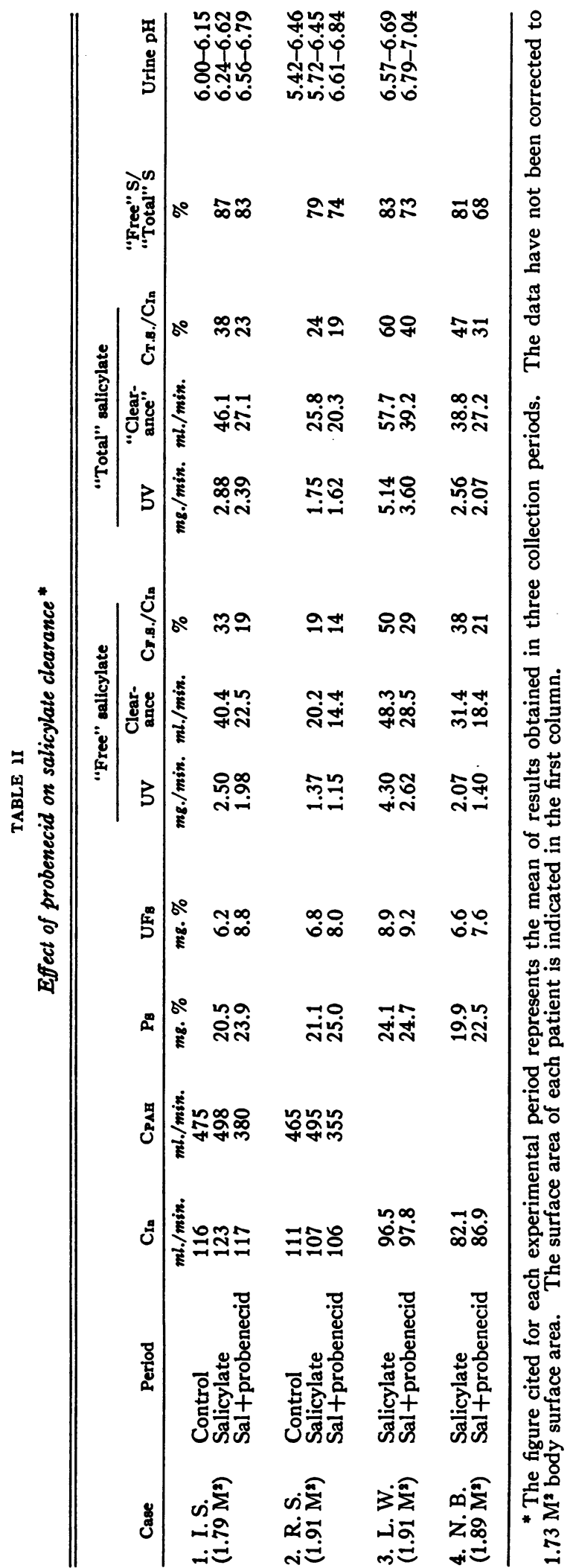


ble and from these data it may be possible to draw inferences as to the processes of tubular participation not amenable to direct measurement.

\section{Tubular reabsorption of free salicylate}

It is apparent from the data in Table I that in man, under the ordinary circumstances of excretion of acid urine, the filtered load of "free" salicylate greatly exceeds the quantity of "free" (and "total") salicylate simultaneously appearing in the urine. In these circumstances most of the "free" salicylate presumably is reabsorbed in the tubules.

As the urine $\mathrm{pH}$ rises after administration of sodium bicarbonate (Figure 2), the salicylate clearance increases $(6-8,19-21)$. This is not associated with an increase in the ultrafiltrable fraction of the plasma salicylate (Figure 1), or with enhancement of the glomerular filtration rate (Table I), hence cannot be ascribed to augmentation of the quantity of salicylate filtered at the glomerulus. It has been inferred $(3,8,21)$ that tubular reabsorption of salicylate decreases as the urinary $\mathrm{pH}$ rises.

Our data are entirely consistent with this view since the "net" tubular reabsorption of "free" salicylate was found to decrease sharply as the urine $\mathrm{pH}$ rose with administration of bicarbonate (Figure 3). Nevertheless, it should be pointed out that the quantity of salicylate reabsorbed in the tubules cannot be determined precisely by the techniques employed because of limitations in measurements and the possibility of concomitant tubular excretion.

At present, one can only speculate as to whether tubular reabsorption of salicylate involves "active" as well as "passive" transport, and whether the inhibiting effect of bicarbonate administration can be explained solely on the basis of changes in $\mathrm{H}^{+}$gradient and related factors in the tubular urine. Penetration of salicyl into cells being a function of $\mathrm{pK}$, the renal tubular epithelium presumably is less permeable to dissociated than to non-dissociated salicylate. Smith (3) has suggested that the decreased salicylate reabsorption at increasing urine $\mathrm{pH}$ can be accounted for by the increased ratio of ionized to non-ionized salicylate in the tubular urine over the $\mathrm{pH}$ range in question, 5.0 to 8.0. As Dalgaard-Mikkelsen (20) points out, however, the $\mathrm{pK}$ of salicylic acid is about 3 and there is consequently little change in dissociation over this $\mathrm{pH}$ range, as is clearly brought out in titration curves recorded by Kapp and Coburn (4). Berliner (22) suggests that active transport of salicylate nevertheless need not be postulated: "If relatively complete impermeability to the ionized form exists and if equilibrium between tubule lumen and peritubule fluid occurs, the concentration of un-ionized salicylate must approach equality within and without the tubule. Under such conditions the observed changes in excretion (including excretion, in alkaline urine, of amounts in excess of those filtered) would be predicted." There are no data available, however, to indicate whether such a mechanism adequately accounts for the rate and magnitude of tubular reabsorption of salicylate without further postulation of specific enzyme transport systems. It should be pointed out that tubular enzyme systems may be presumed to play an at least indirect role in tubular reabsorption of salicylate; for example, in the regulation of $\mathrm{H}^{+}$exchange and through the acceleration of tubular transfer by the concentration gradient produced by conjugation of free salicylate within the tubule cell.

\section{Tubular excretion of free salicylate and salicyl conjugates}

When tubular reabsorption of free salicylate is sufficiently suppressed by administration of sodium bicarbonate, salicylate/inulin clearance ratios in excess of 1.0 are obtained (Figure 2). In one of our patients $(\mathrm{H}$. W., who received the largest injection of bicarbonate) the "free" salicylate/inulin clearance ratio consistently reached 1.8 or more when the urinary $\mathrm{pH}$ was greater than 7.5 ; in five other cases the ratio rose to 1.0 to 1.2 . Similar findings are reported by Bjørneboe, Dalgaard-Mikkelsen, and Raaschou (19) in man and by Davis and Smith (21) in the dog, both groups using thiosulfate clearance as a measure of glomerular filtration rate; however, the latter investigators did not consider the results to be of special significance. In rabbits, Dalgaard-Mikkelsen (20) obtained salicylate clearances five times greater than the creatinine clearance when the urine was sufficiently alkalinized.

Tubular excretion of free salicylate may thus 
become manifest when the urine is alkaline. "Substantial" tubular excretion of salicyluric acid ( $o$-hydroxyhippuric acid) has been shown by Smith and his co-workers (13) to occur in man without alkalinization of the urine. It would therefore appear that tubular excretion of salicylate, at least in conjugated form, regularly occurs at all levels of urinary $\mathrm{pH}$ but ordinarily is masked by preponderant tubular reabsorption of free salicylate $(19,20)$.

\section{Conjugation of salicylate}

Under the ordinary circumstances of oral administration of salicylate and excretion of acid urine, approximately 80 per cent of the salicyl eliminated is in conjugated form-some 55 to 60 per cent combined with glycine and 20 to 25 per cent as glucuronide (4). The proportion of salicyl conjugate falls sharply as the urine $\mathrm{pH}$ rises when bicarbonate is ingested together with salicylate. The same general behavior is noted when salicylate is given intravenously and bicarbonate is then also injected (Table I), but the initial ratio "free" salicylate/"total" salicylate was higher in most of our cases, for reasons already suggested.

Information as to the precise sites and mechanisms of salicylate conjugation in man is wanting. It has been inferred that the low plasma concentration of salicyl conjugates, too low to be measured by currently available methods, implies that conjugation occurs almost exclusively in the kidneys. This assumption is not warranted, however, since the available data are consistent with the possibility that both salicyluric acid and salicyl glucuronide may be derived, in part, from the liver or other extra-renal sources.

That the kidney is nevertheless an important site at least of salicyluric acid formation may be inferred from what is known about biosynthesis of an analog, hippuric acid. The classic studies of Bunge and Schmiedeberg (23) demonstrated that in the dog conjugation of benzoic acid with glycine takes place in the kidney. Perfusion experiments with human kidneys showed that the renal tissue of man also is capable of this transformation (24). Recently, the renal and hepatic enzyme systems responsible for hippurate synthesis have been studied extensively and it has been shown that the benzoyl thioester of coenzyme
A is the energy-rich intermediate (25). Glycine $\mathrm{N}$-acylase has been shown to transfer the benzoyl group from acyl coenzyme A to glycine (26). The role of glycine $\mathrm{N}$-acylase in respect to salicyluric acid formation has not been elucidated, however, because the activator systems in the species studied thus far are incapable of forming the o-hydroxybenzoyl thioester of coenzyme A. No data are available as to the scope of activity of equivalent enzyme systems in human kidney.

\section{Effect of probenecid}

Beyer and his associates (27) have shown that probenecid inhibits the conjugation of $p$-aminobenzoic acid (PAB) and of p-aminosalicylic (PAS) with glycine; in the case of $P A B$, directly or indirectly at the level of acetate activation $(28,29)$. Conjugation of PAB with glucuronic acid apparently is not interfered with by probenecid (30). PAB given concurrently with salicylate decreases urinary excretion of salicylate, apparently by competitively inhibiting formation of salicyluric acid (31).

It might be expected by analogy with such experiments that probenecid would interfere with conjugation of salicylate with glycine in the renal tubules, thus causing a reduction in urinary excretion of salicyl compounds. In the four experiments cited in Table II of this study, probenecid, infused at a rate sufficient to effect a distinct fall in $\mathrm{C}_{\mathbf{P A B}}$, caused a significant decline in salicylate/ inulin clearance ratio in each instance. The effect was somewhat more marked in respect to "free" salicylate, however, and indeed the ratio of "free" to. "total" salicylate excreted in the urine invariably fell. The significance of this result is not clear; tubular secretion of "free" salicylate may be inhibited by probenecid.

\section{SUMMARY}

1. Simultaneous renal clearance studies of salicylate, inulin, and p-aminohippurate were carried out in 10 human subjects, and the effect of alkalinization of the urine by concomitant injection of bicarbonate was determined.

2. $\mathrm{C}_{\text {In }}$ and $\mathrm{C}_{\mathbf{P A B}}$ were not consistently affected by infusion of sodium salicylate alone or in combination with sodium bicarbonate. Administra- 
tion of sodium bicarbonate had no influence on the proportion of plasma salicylate which is ultrafiltrable.

3. The "free" salicylate/inulin clearance ratios ranged from 5 to 60 per cent with a mean of 28.3 per cent. As the urinary $\mathrm{pH}$ rose with infusion of sodium bicarbonate, the salicylate clearance increased to a mean approximately three-fold and the "net" tubular reabsorption of "free" salicylate decreased correspondingly. When the urine $\mathrm{pH}$ exceeded 7.5 the salicylate excreted usually exceeded that filtered, implying tubular excretion of "free" salicylate and salicyl conjugates under these circumstances.

4. The effect of probenecid on salicylate clearance was studied in four cases. Probenecid caused a mean decline of 33 per cent and 40 per cent in "total" and "free" salicylate/inulin clearance ratios, respectively.

5. The data indicate that renal elimination of administered salicylate is a complex four-phase process involving filtration at the glomerulus, tubular reabsorption, tubular conjugation and tubular excretion. Extra-renal conjugation and oxidation also occur.

\section{REFERENCES}

1. Yü, T. F., Sirota, J. H., and Gutman, A. B., Influence of plasma salicylate concentration on urate clearance in man. Clin. Research Proceedings, 1953, 1, 107.

2. Gross, M., and Greenberg, L. A., The Salicylates. New Haven, Hillhouse Press, 1948.

3. Smith, P. K., Certain aspects of the pharmacology of the salicylates. Pharmacol. Reviews, 1949, 1, 353.

4. Kapp, E. M., and Coburn, A. F., Urinary metabolites of sodium salicylate. J. Biol. Chem., 1942, 145, 549.

5. Brodie, B. B., Udenfriend, S., and Coburn, A. F., Determination of salicylic acid in plasma. J. Pharmacol. \& Exper. Therap., 1944, 80, 114.

6. Smith, P. K., Gleason, H. L., Stoll, C. G., and Ogorzalek, S., Studies on the pharmacology of salicylates. J. Pharmacol. \& Exper. Therap., 1946, 87, 237.

7. Williams, F., and Leonards, J. R., The effect of sodium bicarbonate on the renal excretion of salicylate. J. Pharmacol. \& Exper. Therap., 1948, 93, 401.

8. Hoffman, W. S., and Nobe, C., The influence of urinary $\mathrm{pH}$ on the renal excretion of salicyl derivatives during aspirin therapy. J. Lab. \& Clin. Med., 1950, 35, 237.
9. Smith, H. W., The Kidney. Structure and Function in Health and Disease. New York, Oxford University Press, 1951.

10. Sirota, J. H., Yü, T. F., and Gutman, A. B., Effect of benemid ( $p$-[di-n-propylsulfamyl]-benzoic acid) on urate clearance and other discrete renal functions in gouty subjects. J. Clin. Invest., 1952, 31, 692.

11. Goldring, W., and Chasis, H., Hypertension and $\mathrm{Hy}-$ pertensive Diseases. New York, The Commonwealth Fund, 1944.

12. Schreiner, G. E., Determination of inulin by means of resorcinol. Proc. Soc. Exper. Biol. \& Med., 1950, 74, 117.

13. Smith, H. W., Finkelstein, N., Aliminosa, L., Crawford, B., and Graber, M., The renal clearances of substituted hippuric acid derivatives and other aromatic acids in dog and man. J. Clin. Invest., 1945, 24, 388.

14. Simms, H. S., and Sanders, M., Use of serum ultrafiltrate in tissue cultures for studying deposition of fat and for propagation of viruses. Arch. Path., 1942, 33, 619.

15. McLean, F. C., and Hastings, A. B., The state of calcium in the fluids of the body. 1. The conditions affecting the ionization of calcium. J. Biol. Chem., 1935, 108, 285.

16. Smull, K., Wégria, R., and Leland, J., The effect of sodium bicarbonate on the serum salicylate level during salicylate therapy of patients with acute rheumatic fever. J.A.M.A., 1944, 125, 1173.

17. Chabanier, H., Lebert, M., and Lobo-Onell, C., De l'absorption du salicylate de soude par le sérum sanguin. Compt. rend. Soc. de biol., 1923, 88, 178.

18. Lester, D., Lolli, G., and Greenberg, L. A., The fate of acetylsalicylic acid. J. Pharmacol. \& Exper. Therap., 1946, 87, 329.

19. Bjørneboe, M., Dalgaard-Mikkelsen, S., and Raaschou, F., On the excretion of salicylic acid in man (a preliminary report). Scandinav. J. Clin. \& Lab. Invest., 1949, 1, 287.

20. Dalgaard-Mikkelsen, S., On the renal excretion of salicylate. Acta pharmacol. et toxicol., 1951, 7, 243.

21. Davis, P. L., and Smith, P. K., Relation of rate of excretion of salicylate to urinary acidity. Arch. internat. de pharmacodyn. et de thérap., 1951, 86, 303.

22. Berliner, R. W., The kidney. Ann. Rev. Physiol., 1954, 16, 269.

23. Bunge, G., and Schmiedeberg, O., Ueber die Bildung der Hippursäure. Arch. f. exper. Path. u. Pharmakol., 1876, 6, 233.

24. Snapper, I., Grünbaum, A., and Neuberg, G., Ueber die Hippursäuresynthese in der überlebenden Niere von verschiedenen Tiergattungen, auch vom Menschen. Biochem. Ztschr., 1924, 145, 40. 
25. Schachter, D., and Taggart, J. V., Benzoyl coenzyme A and hippurate synthesis. J. Biol. Chem., 1953, 203, 925.

26. Schachter, D., and Taggart, J. V., Glycine N-acylase. Purification and properties. J. Biol. Chem., 1954, 208, 263.

27. Beyer, K. H., Wiebelhaus, V. D., Tillson, E. K., Russo, H. F., and Wilhoyte, K. M., "Benemid," p-(di-n-propylsulfamyl)-benzoic acid: Inhibition of glycine conjugative reactions. Proc. Soc. Exper. Biol. \& Med., 1950, 74, 772.

28. Taggart, J. V., Enzymatic processes in tubular secretory transport. Trans. Third Conf. on Renal
Function, 1951, p. 201, Josiah Macy, Jr. Foundation, N. Y., 1952.

29. Wiebelhaus, V. D., Beyer, K. H., and Nolan, F. C., Enzymatic mechanisms involved in the renal secretion of PAH. Federation Proc., 1954, 13, 164.

30. Beyer, K. H., Functional characteristics of renal transport mechanisms. Pharmacol. Reviews, 1950, 2, 227.

31. Salassa, R. M., Bollman, J. L., and Dry, T. J., The effect of para-amino-benzoic acid on the metabolism and excretion of salicylate. J. Lab. \& Clin. Med., 1948, 33, 1393. 